\title{
Centrifugal Consolidation Testing of Soils for Classification Purposes
}

by John F. Peters, Tina L. Holmes, Daniel A. Leavell

\author{
U.S. Army Corps of Engineers \\ Waterways Experiment Station \\ 3909 Halls Ferry Road \\ Vicksburg, MS 39180-6199
}

Donald R. Snethen

Oklahoma State University

Stillwater, OK 74074

Final report

Approved for public release; distribution is unlimited

Prepared for U.S. Army Corps of Engineers

Warhinarnr. nr, onz14-1000 